\title{
Formulasi sabun karika (Carica pubescens) sebagai sabun kecantikan dan
}

\section{kesehatan}

Carica (Carica pubescens) soap formulation as a beauty and health soap

\author{
Roisatul Ainiyah ${ }^{1)}$, Cahyaning Riniutami ${ }^{1)}$ \\ ${ }^{1}$ Universitas Yudharta Pasuruan, Pasuruan, Indonesia \\ Email: roisatul.ainiyah@yudharta.ac.id
}

Informasi artikel:

Dikirim: $12 / 10 / 2019$

ditinjau: 20/10/2019

disetujui: 10/03/2020

\section{(c) (i)}

Copyright (c) 2020

Roisatul Ainiyah,

Cahyaning Riniutami

\begin{abstract}
Soap is a mixture of sodium compounds with fatty acids that are used as a body cleansing agent, in the form of solid, foam, with or without other additives and does not cause irritation to the skin. To improve quality, bath soap can be given additional ingredients that contain vitamins and various nutrients needed by the skin such as the addition of extracts of carika fruit (Carica pubescens). The purpose of this research is to find out the right formulation in making carika soap. This research used an experimental method with randomized block design (RCBD), consisting of two factorial variations in the concentration of karika juice $10 \%, 100 \%, 80 \%, 60 \%)$ and variations in the concentration of $\mathrm{NaOH}(30 \%, 35 \%$, and 40\%) so that 12 treatments were obtained each with 3 replications. The process of making soap uses the hot process method. Soap quality analysis is carried out by comparing the results of chemical tests for carika soap with SNI 06-35321994 (SNI for solid bath soap), foam stability test, soap hardness, and organoleptic test. The data obtained were analyzed using ANOVA with a confidence interval of 5\%. If an effect is found on one of the variebel, a further Tukey test is performed. The results showed that the water content, $\mathrm{pH}$, and free alkali did not meet SNI, while the amount of fatty acids and mineral oil was in accordance with $S N I$, the significant difference between treatments was only in the water content. Karika soap has abundant and stable foam. The higher concentration of karika juice make the lower hardness of the soap. Organoleptic test results showed a low level of preference for panelists on karika soap products. The suggestion from this research is that karika juice can be tried to applied it in the liquid bath.

Keywords: Soap formulation, beauty soap, carica (Carica pubescens)
\end{abstract}

ABSTRAK: Sabun merupakan campuran dari senyawa natrium dengan asam lemak yang digunakan sebagai bahan pembersih tubuh, berbentuk padat, busa, dengan atau tanpa zat tambahan lain serta tidak menimbulkan iritasi pada kulit. Untuk meningkatkan kualitas, sabun mandi dapat diberi bahan tambahan yang mengandung vitamin dan berbagai macam nutrisi yang dibutuhkan kulit misalnya buah karika (Carica pubescens). Tujuan dari penelitian ini adalah untuk mengetahui formulasi yang tepat dalam pembuatan sabun karika. Penelitian ini menggunakan metode eksperimen dengan rancangan acak kelompok (RAK), terdiri dari dua faktorial yaitu variasi konsentrasi sari buah karika $(0 \%, 100 \%, 80 \%, 60 \%)$ dan variasi konsentrasi $\mathrm{NaOH}(30 \%$, 35\%, dan 40\%) sehingga didapatkan 12 perlakuan masing-masing dengan 3 kali ulangan. Proses pembuatan sabun menggunakan metode hot process. Analisa mutu sabun dilakukan dengan membandingkan hasil uji kimia sabun karika dengan SNI sabun mandi padat uji stabilitas busa, kekerasan sabun, dan uji organoleptik. Data yang diperoleh dianalisis menggunakan ANOVA dengan selang kepercayaan 5\%. Apabila ditemukan pengaruh terhadap salah satu variebel maka dilakukan uji lanjut Tukey. Hasil penelitian menunjukkan bahwa kadar air, $\mathrm{pH}$, dan alkali bebas tidak memenuhi SNI, sedangkan jumlah asam lemak dan minyak mineral telah sesuai dengan SNI, perbedaan signifikan antar perlakuan hanya ada pada kadar air. Sabun karika memiliki busa melimpah dan 
stabil. Semakin tinggi konsentrasi sari buah karika maka kekerasan sabun semakin rendah. Hasil uji organoleptik menunjukkan tingkat kesukaan panelis terhadap produk sabun karika rendah. Saran dari kegiatan penelitian ini adalah sari buah karika dapat dicoba untuk diaplikasikan pada pembuatan sabun mandi cair.

Kata kunci: Formulasi sabun, sabun kecantikan, karika (Carica pubescens)

Sitasi: Ainiyah, R., \& Utami, C. R. (2019). Formulasi sabun karika (Carica pubescens) sebagai sabun kecantikan dan kesehatan. AGROMIX, 11(1), 920. https://doi.org/10.35891/agx.v11i1.1652

\section{PENDAHULUAN}

Kecantikan dan kesehatan kulit menjadi aspek yang mulai diperhatikan oleh masyarakat. Permintaan pasar terhadap produk kecantikan dan kesehatan kulit semakin meningkat (Abdullah dkk., 2012; Hassali dkk., 2015; Wijesundera \& Abeysekera, 2010). Sabun mandi merupakan salah satu produk kecantikan dan kesehatan kulit. Sabun mandi adalah produk perawatan kulit yang setiap hari dipakai oleh masyarakat. Pada awalnya sabun mandi hanya berfungsi sebagai alat pembersih tubuh ketika mandi, tetapi saat ini sabun mandi juga berfungsi sebagai media untuk mempercantik kulit dengan cara menambahkan berbagai zat baik alami atau buatan dengan tujuan untuk memperbaiki kondisi kulit baik demi kecantikan maupun kesehatan (Ashfaq \& Ali, 2017).

Sabun merupakan campuran dari senyawa natrium dengan asam lemak yang digunakan sebagai bahan pembersih tubuh, berbentuk padat, busa, dengan atau tanpa zat tambahan lain serta tidak menimbulkan iritasi pada kulit (BSNI, 1994; Oluwatoyin, 2011; Widyasanti dkk., 2017). Sabun mandi merupakan produk yang dihasilkan dari reaksi antara minyak atau lemak dengan basa melalui proses saponifikasi (Laily dkk., 2012;
Oluwatoyin, 2011). Basa yang umum digunakan untuk membuat sabun mandi adalah $\mathrm{NaOH}$ atau $\mathrm{KOH}$. Sabun mandi bisa berbentuk padat, cair dan berbusa. $\mathrm{NaOH}$ banyak digunakan dalam pembuatan sabun padat karena sifatnya yang tidak mudah larut dalam air (Betsy dkk., 2013; Nadarajan \& Ismail, 2011; Oluwatoyin, 2011).

Sabun mandi sebagai produk perawatan kulit perlu ditingkatkan kualitasnya mengingat kebutuhan konsumen akan kecantikan dan kesehatan kulit sebagian besar bergantung pada sabun mandi (Ogunsuyi \& Akinnawo, 2012). Untuk meningkatkan kualitas, sabun mandi dapat diberi bahan tambahan yang mengandung vitamin dan berbagai macam nutrisi yang dibutuhkan kulit, selain itu juga dapat ditambahkan bahan aktif yang mampu mengurangi mikroorganisme patogen pada kulit (Putri, 2017). Bahan tambahan dapat berupa bahan alami, misalnya sari buah-buahan atau bahan herbal lain yang tersedia di lingkungan sekitar. Salah satu bahan alami yang dapat ditambahkan pada sabun mandi adalah sari buah karika (Carica pubescens).

Buah karika merupakan salah satu buahbuahan yang dapat ditemukan di Dataran Tinggi Dieng, Kabupaten Wonosobo (Hidayat, 2001). 
Buah karika merupakan tumbuhan dataran tinggi yang mengandung cukup nutrisi untuk membantu merawat kesehatan dan kecantikan kulit. Berdasarkan hasil penelitian, kandungan buah karika terdiri dari vitamin C sebesar 65,12 mg / 100g, vitamin A sebesar 1771,1 mg / 100 g, Ca sebesar 24 ppm, Fe 1,2 ppm, P 0,0254\% (Kusnadi dkk., 2016). Hasil uji kuantitatif menunjukkan bahwa pada C. pubescens yang tumbuh di kawasan Cangar memiliki kandungan total flavanoid ekuivalen kuersetin sebesar 800 $\mathrm{mg} / \mathrm{L}$, di Bromo sebesar 816,65 mg/ L, dan Dataran Tinggi Dieng sebesar 633,35 mg/L (Minarno, 2015). Selain Dieng, buah karika juga tumbuh subur di dataran tinggi Tengger.

Pemanfaatan buah karika di Tengger sejauh ini hanya sebatas untuk makanan olahan seperti manisan dan sari buah. Produksinya pun masih tergantung pesanan, dikarenakan kendala pemasaran. Kendala utama dalam proses pemasaran adalah belum adanya BPOM yang mereka miliki, karena manisan dan sari buah berbentuk cair sehingga ijin produksi tidak bisa hanya sebatas PIRT. Diperlukan adanya inovasi dalam pengolahan buah karika, sehingga buah kaya manfaat ini dapat dimanfaatkan dengan baik. Salah satu inovasi pengolahannya dapat berupa pengolahan non pangan, yaitu menjadi sabun, mengingat karika kaya akan nutris yang dibutuhkan kulit.

Buah karika dapat dipakai sebagai bahan tambahan pada sabun karena memiliki kandungan saponin yang merupakan surfaktan alami yang bersifat seperti sabun atau deterjen, antioksidan, flavonoid, dan senyawa antibakteri karena mengandung senyawa polifenol, tannin dan triterpenoid (Minarno, 2015). Dengan kandungan tersebut buah karikan sangat berpotensi dalam pembuatan sabun dengan manfaat yang besar. Oleh karena itu, penelitian mengenai formulasi sabun karika (Carica pubescens) sebagai sabun kecantikan dan kesehatan perlu untuk dilakukan. Tujuan dari penelitian ini adalah untuk mengetahui formulasi yang tepat dalam pembuatan sabun karika (Carica pubescens) sebagai sabun kecantikan dan kesehatan berdasarkan hasil uji kimia dan organoleptik sabun.

\section{METODE PENELITIAN}

\section{Alat dan bahan}

Alat yang digunakan dalam penelitian ini meliputi pengaduk, baskom, Hot Plate, blender, $\mathrm{pH}$ indikator universal, neraca analitik, dan peralatan gelas seperti: gelas ukur, pipet tetes, gelas piala, dan pengaduk kaca. Sedangkan bahan yang digunakan dalam penelitian ini adalah buah karika varietas lokal (Carica pusbescens) yang diambil dari dataran tinggi Tengger, minyak kelapa sawit (Merk Bimoli), $\mathrm{NaOH}, \mathrm{Cocamide}-\mathrm{DEA}$, dan aquades.

\section{Rancangan penelitian}

Rancangan percobaan disajikan pada Tabel 3.1. 
Faktor 1 (variasi konsentrasi sari buah karika)

$\mathrm{CO}$ = tanpa penambahan sari buah karika

$\mathrm{C} 1$ = penambahan sari buah karika $100 \%$

C2 = penambahan sari buah karika $80 \%$

C3 = penambahan sari buah karika $60 \%$

Faktor 2 (variasi konsentrasi $\mathrm{NaOH}$ )

$\mathrm{K} 1=$ penambahan $\mathrm{NaOH} 30 \%$

$\mathrm{K} 2$ = penambahan $\mathrm{NaOH} 35 \%$

$\mathrm{K} 3$ = penambahan $\mathrm{NaOH} 40 \%$

Tabel 1. Rancangan percobaan

\begin{tabular}{|c|c|c|c|c|}
\hline \multirow{3}{*}{$\begin{array}{c}\text { Volume } \\
\text { sari karika }\end{array}$} & \multirow{3}{*}{ Ulangan } & \multicolumn{3}{|c|}{ Konsentrasi $\mathrm{NaOH}$} \\
\hline & & $\mathrm{K} 1=$ & $K 2=$ & $K 3=$ \\
\hline & & $30 \%$ & $35 \%$ & $40 \%$ \\
\hline \multirow{6}{*}{$\begin{array}{c}\text { CO } \\
\text { (kontrol) }\end{array}$} & C0.1 & C0.1 & C0.1 & C0.1 \\
\hline & & K1 & K2 & K2 \\
\hline & $\mathrm{CO} .2$ & $\mathrm{C} 0.2$ & $\mathrm{C} 0.2$ & $\mathrm{CO} .2$ \\
\hline & & K1 & $\mathrm{K} 2$ & $\mathrm{~K} 2$ \\
\hline & $\mathrm{CO} 0.3$ & $\mathrm{C} 0.3$ & $\mathrm{C} 0.3$ & $\mathrm{C} 0.3$ \\
\hline & & K1 & K2 & K2 \\
\hline \multirow{6}{*}{ C1 (100\%) } & C1.1 & C1.1 & C1.1 & C1.1 \\
\hline & & K1 & $\mathrm{K} 2$ & $\mathrm{~K} 2$ \\
\hline & C1.2 & C1.2 & C1.2 & C1.2 \\
\hline & & K1 & K2 & K2 \\
\hline & C1.3 & C1.3 & C1.3 & C1.3 \\
\hline & & K1 & K2 & K2 \\
\hline \multirow{6}{*}{ C2 (80\%) } & C2.1 & C2.1 & C2.1 & C2.1 \\
\hline & & K1 & K2 & K2 \\
\hline & $\mathrm{C} 2.2$ & C2.2 & $\mathrm{C} 2.2$ & $\mathrm{C} 2.2$ \\
\hline & & K1 & K2 & K2 \\
\hline & C2.3 & C2.3 & C2.3 & $\mathrm{C} 2.3$ \\
\hline & & K1 & K2 & K2 \\
\hline \multirow{6}{*}{ C3 (60\%) } & C3.1 & C3.1 & C3.1 & C3.1 \\
\hline & & K1 & $\mathrm{K} 2$ & $\mathrm{~K} 2$ \\
\hline & C3.2 & C3.2 & C3.2 & $\mathrm{C} 3.2$ \\
\hline & & K1 & $\mathrm{K} 2$ & $\mathrm{~K} 2$ \\
\hline & C3.3 & C3.3 & C3.3 & C3.3 \\
\hline & & K1 & K2 & K2 \\
\hline
\end{tabular}

\section{Prosedur penelitian}

Prosedur penelitian secara ringkas disajikan pada gambar 1.

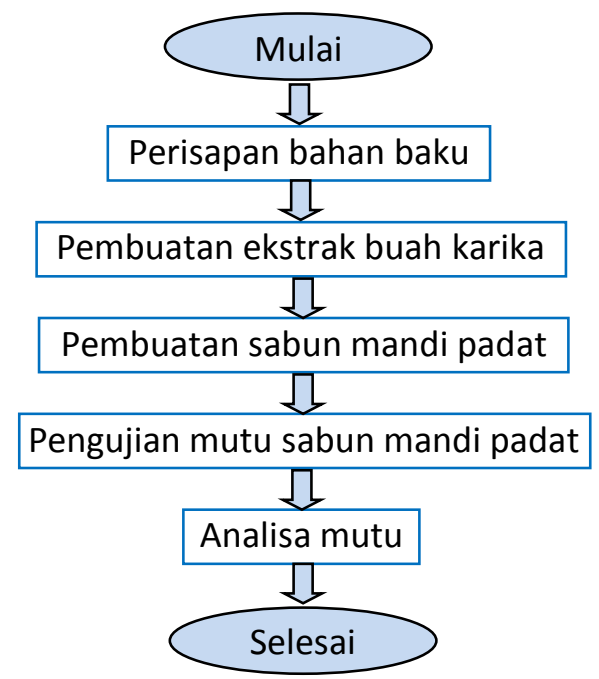

Gambar 1. Diagram alir prosedur penelitian

\section{Persiapan bahan baku dan pembuatan sari} buah karika

Bahan baku utama berupa buah karika diambil langsung dari dataran tinggi Tengger. Buah karika dikupas, dibuang bijinya, kemudian dicuci hingga bersih. Selanjutnya diblender, disaring untuk diambil sarinya. Sari yang didapat diasumsikan mengandung konsentrasi $100 \%$, kemudian diencerkan menjadi $80 \%$, dan $60 \%$.

\section{Pembuatan sabun padat}

Pertama membuat larutan alkali dengan menambahkan $\mathrm{NaOH}$ dalam gelas piala yang sudah diisi dengan aquades, sesuai dengan rancangan percobaan, yaitu 30\%, 35\%, dan 40\%. Minyak sayur dipanaskan hingga suhu $\pm 50-60^{\circ} \mathrm{C}$ kemudian ditambahkan $10 \mathrm{ml}$ cocamide-DEA. Selanjutnya, larutan alkali dicampur dengan campuran minyak, diaduk sampai terjadi trace (mengental), kemudian ditambah $40 \mathrm{ml}$ sari buah karika (100\%, 80\%, $60 \%)$ sesuai dengan rancangan percobaan, 
dengan pelan-pelan dicampurkan ketika larutan sudah agak dingin. Ditunggu sampai larutan mengental membentuk biang sabun dan dihentikan pengadukan, kemudian dipanaskan lagi dengan suhu di atas $70^{\circ} \mathrm{C}$. Kemudian dituang dalam cetakan dan didiamkan selama 2 minggu agar terjadi curing dan proses penyabunan berjalan sempurna.

\section{Uji kualitas sabun}

Uji kualitas sabun padat menggunakan parameter kimia (analisa kadar air, jumlah asam lemak, alkali bebas, asam lemak bebas, lemak tak tersabunkan, $\mathrm{pH}$ ), parameter fisik (kekerasan, stabilitas busa), serta uji organoleptik (warna, aroma, kekentalan, banyak busa) (BSNI, 2006).

\section{Analisa data}

Analisa data hasil uji fisik dan kimia sabun dilakukan dengan statistika deskriptif. Hasil uji kimia sabun kemudian dianalisis berdasarkan SNI sabun mandi padat dan dengan ANOVA (selang kepercayaan 5\%). Hasil uji organoleptik dianalisis secara deskriptif persentatif.

\section{HASIL DAN PEMBAHASAN}

\section{Kadar air sabun karika}

Analisis kadar air sabun dilakukan dengan metode gravimetri (metode oven). Data hasil analisis kadar air sabun karika disajikan pada Gambar 2. berikut.

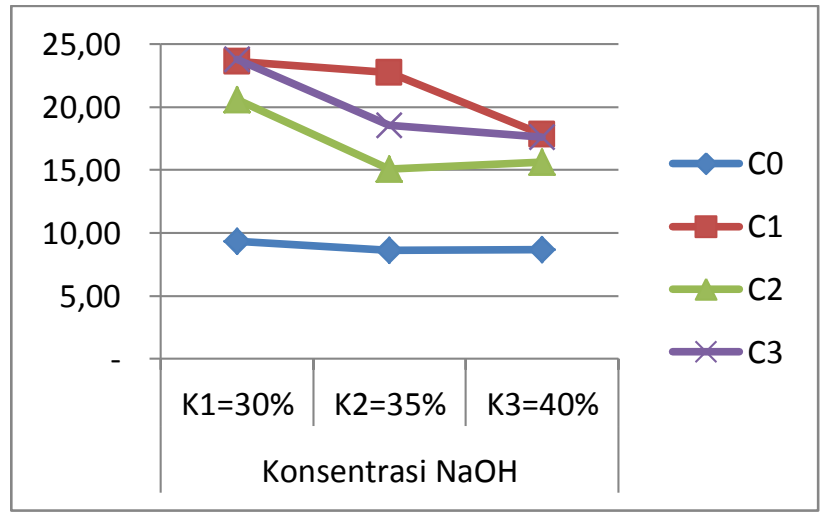

Gambar 2. Grafik kadar air sabun karika

Berdasarkan SNI 06-3532-1994 sabun mandi padat, kadar air maksimal adalah 15\%, sedangkan data hasil analisis kadar air sabun mandi karika berada pada rentangan 8,60\% 23,76\% (BSNI, 1994). Data kadar air di bawah $15 \%$ ada pada perlakuan CO (tanpa penambahan sari karika). Hal ini berarti bahwa kadar air sabun karika hasil penelitian tidak memenuhi SNI.

Dari berat total bahan sabun, bahan cair berasal dari sari buah karika dan larutan $\mathrm{NaOH}$ yaitu sebesar $48,8 \%$. Hasil penelitian Sameng (2013) juga menunjukkan 48\% bahan (dari bobot total $200 \mathrm{ml}$ ) berbentuk cairan yang berasal dari sari beras dan larutan alkali menghasilkan sabun dengan kadar air berkisar antara 4,125\% - 4,312\%. Dari hasil uji ANOVA diketahui bahwa nilai signifikasi $0,000<0,05$ yang berarti ada perbedaan signifikan antar perlakuan.

Semakin tinggi proporsi volume air pada bahan dasar sabun maka semakin lambat laju reaksi saponifikasi dan semakin tinggi kadar air maka struktur sabun akan semakin membentuk gel (kental) (Kenna, 2016). Jenis dan 
perbandingan minyak yang digunakan memiliki pengaruh yang nyata terhadap kadar air sabun padat yang dihasilkan, namun tidak memiliki pengaruh terhadap kadar asam lemak bebas dan persentasi busa (Choir, 2015). Tingginya kadar air juga menyebabkan proses penguapan air saat fase curing menjadi lebih lama, hal ini juga menghambat percepatan reaksi saponifikasi. Tingginya kadar air sabun karika diduga disebabkan beberapa faktor. Pertama tingginya komposisi penggunaan bahan cair sabun. Kedua proses pengadukan pada saat pencampuran larutan alkali dan minyak. Ketiga, cara penyimpanan pada saat proses curing yang menyebabkan penguapan kandungan air tidak berjalan baik.

Proses pembuatan sabun karika dilakukan dengan metode hot process pada suhu $\pm 50^{\circ} \mathrm{C}$ $60^{\circ} \mathrm{C}$, kemudian memanaskannya lagi pada suhu tinggi. Keuntungan dari metode ini adalah mempercepat proses saponifikasi (Whitlock, 2010). Keuntungan lainnya adalah pada metode hot process gliserol yang terbentuk tidak dipisahkan dari sabun, ketika sabun digunakan gliserol tertinggal di kulit dan berfungsi melembabkan kulit.

Kadar air sabun mempengaruhi daya tahan sabun selama penyimpanan dan sensasi ketika digunakan. Semakin tinggi kadar air sabun maka tingkat kekerasan sabun semakin rendah, sebaliknya semakin rendah kadar air sabun maka tingkat kekerasan sabun akan semakin tinggi, sabun yang keras memiliki daya simpan yang lebih lama serta sensasi lebih baik saat digunakan. Sabun dengan kadar air tinggi akan mengalami penyusutan selama penyimpanan, serta lebih cepat habis ketika digunakan.

Hasil uji orgnoleptik menunjukkan bahwa sabun padat karika lunak dan rapuh, ini dikarenakan kadar air yang terlalu tinggi.

\section{pH sabun}

$\mathrm{pH}$ sabun tidak termasuk dalam SNI sabun padat yang telah ditetapkan, akan tetapi umumnya sabun yang aman digunakan adalah dengan nilai $\mathrm{pH}$ 7-10, di atas $\mathrm{pH} 10$ sabun tidak aman digunakan karena kandungan alkalinya terlalu tinggi. Nilai pH sabun yang terlalu tinggi dapat menyebabkan iritasi kulit, sedangkan nilai $\mathrm{pH}$ yang terlalu rendah juga menyebabkan peningkatan daya absorbsi sabun pada kulit sehingga juga menyebabkan iritasi pada kulit (Hernani, 2010). Data hasil pengukuran pH sabun padat karika berkisar antara 12 - 13 . Berdasarkan uraian di atas $\mathrm{pH}$ ini terlalu tinggi sehingga tidak aman untuk diaplikasikan pada kulit. Secara rinci data $\mathrm{pH}$ sabun karika disajikan pada Gambar 3.

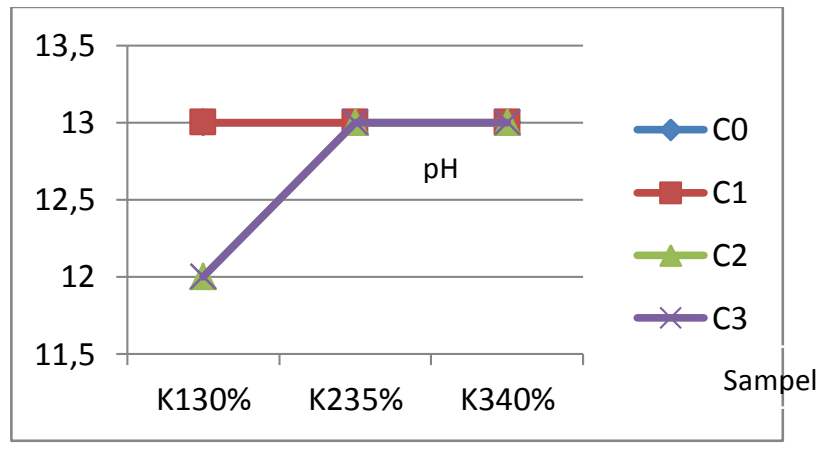

Gambar 3. Grafik pH sabun karika 
$\mathrm{pH}$ sabun yang terlalu tinggi dapat menyebabkan iritasi pada kulit. Dalam proses pembuatan sabun, $\mathrm{pH}$ dipengaruhi oleh keberadaan larutan alkali $(\mathrm{NaOH})$, di mana dalam proses saponifikasi $\mathrm{NaOH}$ akan bereaksi dengan minyak membentuk sabun. $\mathrm{pH}$ yang cenderung tinggi menunjukkan bahwa kadar alkali yang digunakan terlalu tinggi atau reaksi penyabunan tidak berjalan sempurna. Tingginya kadar air sabun dapat menjadi penghambat reaksi saponifikasi.

\section{Kandungan jumlah asam lemak sabun karika}

Jumlah asam lemak adalah keseluruhan asam lemak baik asam lemak yang terikat dengan natrium maupun asam lemak bebas ditambah lemak netral (trigliserida netral/lemak yang tidak tersabunkan/ unsafonified fat), (BSNI, 1994). Sedangkan SNI sabun mandi padat adalah $>10$. Dari 12 perlakuan hanya satu perlakuan C2K3 yang tidak memenuhi SNI. Data jumlah asam lemak sabun karika disajikan pada Gambar 4. Data tersebut kemudian dianalisis menggunakan ANOVA, hasilnya nilai signifikansi 0,239>0,05 sehingga tidak ada perbedaan signifikan antar perlakuan sabun karika.

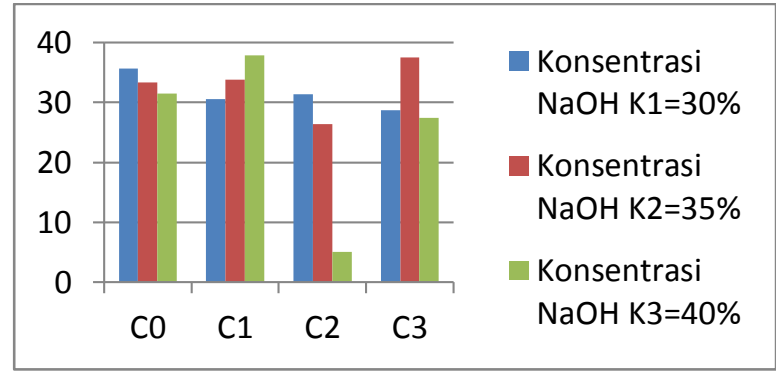

Gambar 4. Diagram jumlah asam lemak sabun karika
Jumlah dan jenis asam lemak akan mempengaruhi karakteristik sabun. Asam lemak jenuh lebih cepat tersaponifikasi daripada asam lemak tak jenuh (Dunn, 2009). Pengujian asam lemak sabun karika menggunakan metode volumetri. Dari pengukuran jumlah asam lemak, sabun karika masuk kategori sabun tipe II.

Kandungan asam lemak bebas/alkali bebas sabun

Asam lemak bebas adalah asam lemak yang berada dalam contoh sabun, tetapi yang tidak terikat sebagai senyawa natrium ataupun senyawa trigliserida (lemak netral). Sedangkan Alkali bebas adalah alkali dalam sabun yang tidak terikat sebagai senyawa (BSNI, 1994). Pengujian asam lemak bebas menggunakan metode volumetri. Setelah dilakukan pengujian kadar asam lemak bebas dari semua sampel adalah 0 sehingga dilanjutkan untuk pengujian alkali bebas. SNI alkali bebas sabun adalah < 2,5. Hasil pengujian alkali bebas sabun karika disajikan pada gambar 5. kadar alkali bebas sabun karika pada semua perlakuan tidak sesuai dengan SNI karena kadarnya melebihi $2,5 \%$.

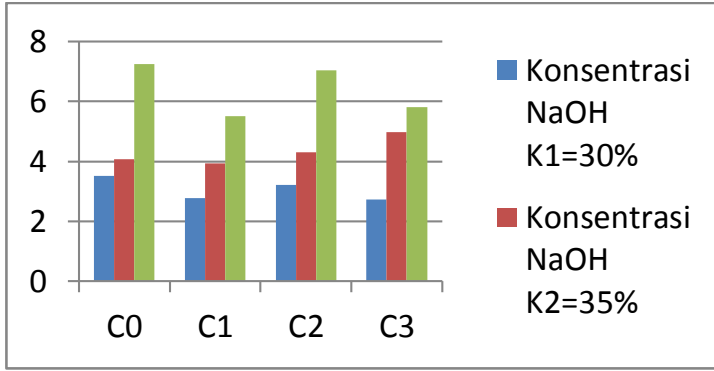

Gambar 5. Diagram jumlah alkali bebas sabun karika 
Dari gambar 5. menunjukkan bahwa semakin tinggi konsentrasi $\mathrm{NaOH}$ maka kandungan alkali bebas juga semakin tinggi. Hasil penelitian Doni (2018) menyatakan bahwa penambahan $\mathrm{NaOH} 35 \%$ pada formulasi sabun menghasilkan sabun dengan kadar alkali bebas 0,0\%. Menurut Dunn (2010) dalam bukunya Scientific Soapmaking menyatakan bahwa hasil survey yang dilakukan terhadap buku resep pembuatan sabun terbitan tahun 1970an s/d 2000an menunjukkan konsentrasi larutan alkali yang digunakan di setiap resep berkisar antara $25 \%$ s/d $37 \%$ menghasilkan sabun dengan kadar alkali bebas berkisar antara $0,1 \mathrm{~s} / \mathrm{d} \quad 0,7$ tergantung pada jenis minyak yang digunakan. Sedangkan Sari (2010) menyatakan bahwa kelebihan alkali dapat disebabkan karena penambahan alkali yang berlebihan pada proses pembuatan sabun. Hal ini dapat diartikan tingginya kadar alkali sabun karika dapat disebabkan penambahan volume larutan $\mathrm{NaOH}$ berlebih. Hal ini juga sesuai dengan hasil pengujian $\mathrm{pH}$, di mana $\mathrm{pH}$ sabun karika yang dihasilkan juga cukup tinggi.

\section{Kandungan lemak tak tersabunkan}

Lemak yang tidak tersabunkan adalah lemak netral/trigliserida netral yang tidak bereaksi selama proses penyabunan atau yang sengaja ditambahkan untuk mendapatkan basil sabun superfat (BSNI, 1994). Belum ada ketentuan SNI untuk kandungan lemak tak tersabunkan. Data uji kandungan lemak tak tersabunkan disajikan pada Gambar 5. Data pengujian kadar lemak tak tersabunkan kemudian dianalisis menggunakan ANOVA dengan selang kepercayaan 0,05\%. Hasilnya nilai signifikasi $0,488>0.05$, sehingga tidak ada perbedaan signifikan antar perlakuan.

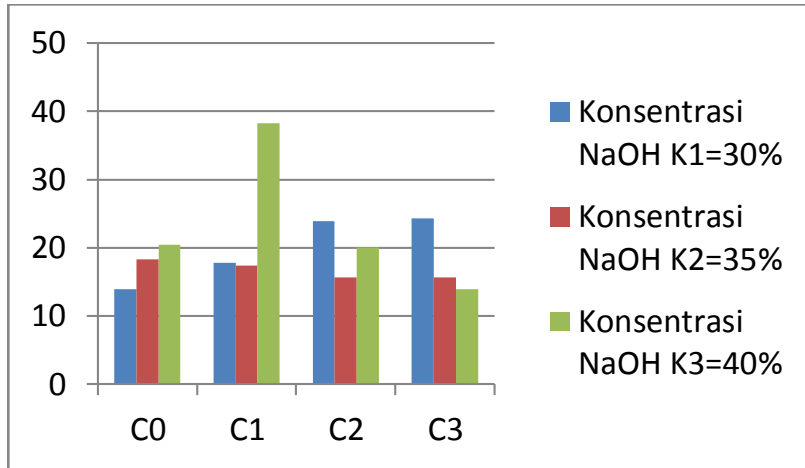

Gambar5. Diagram kandungan lemak tak tersabunkan pada sabun karika

\section{Kandungan minyak mineral sabun}

Minyak mineral tidak mungkin dapat disabunkan seperti halnya asam lemak bebas dan lemak netral, sehingga meskipun sudah disabunkan dengan $\mathrm{KOH}$ berlebihan akan tetap sebagai minyak dan pada penambahan air akan terjadi emulsi antara air dan minyak yang ditandai adanya kekeruhan (BSNI, 1994). SNI minyak mineral sabun mandi padat adalah negatif. Dari pengujian minyak mineral pada 12 perlakuan menunjukkan hasil negatif, sehingga memenuhi SNI 1994.

\section{Stabilitas busa}

Belum ada SNI untuk stabilitas busa sabun mandi padat. Tetapi, sabun yang baik memiliki kecepatan menghasilkan busa dan stabilitas busa yang tinggi. Kedua hal itu dapat dipengaruhi oleh konsentrasi ion logam seperti kalsium $\left(\mathrm{Ca}^{2+)}\right.$ dan magnesium $\left(\mathrm{Mg}^{2+)}\right.$ yang 
terdapat dalam air. Data hasil uji stabilitas busa disajikan pada Gambar 6.

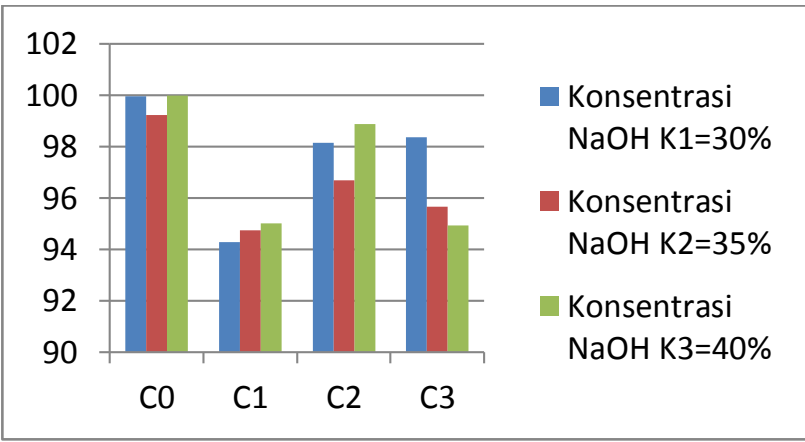

Gambar 6. Diagram hasil pengukuran stabilitas busa sabun karika

Hasil uji stabilitas busa menunjukkan bahwa nilai stabilitas busa terendah adalah 94,7\% sedangkan tertinggi adalah 99,9\%. Karakteristik busa sabun dipengaruhi oleh beberapa faktor yaitu adanya bahan surfaktan, penstabil busa, dan bahan-bahan penyusun sabun cair lainnya (Amin, 2006; Arlianti, 2018). Formulasi sabun karika ini menggunakan penambahan Cocoamide-DEA sebagai agen penambah busa sehingga busa yang dihasilkan lebih banyak dan lebih stabil.

\section{Hasil pengukuran kekerasan sabun}

Pengukuran kekerasan sabun karika dilakukan menggunakan alat penetrometer saku. Semakin tinggi angka yang ditunjukkan pada skala pengukuran penetrometer maka sabun semakin keras. Hasil pengukuran kekerasan sabun disajikan pada gambar 7 . berikut.

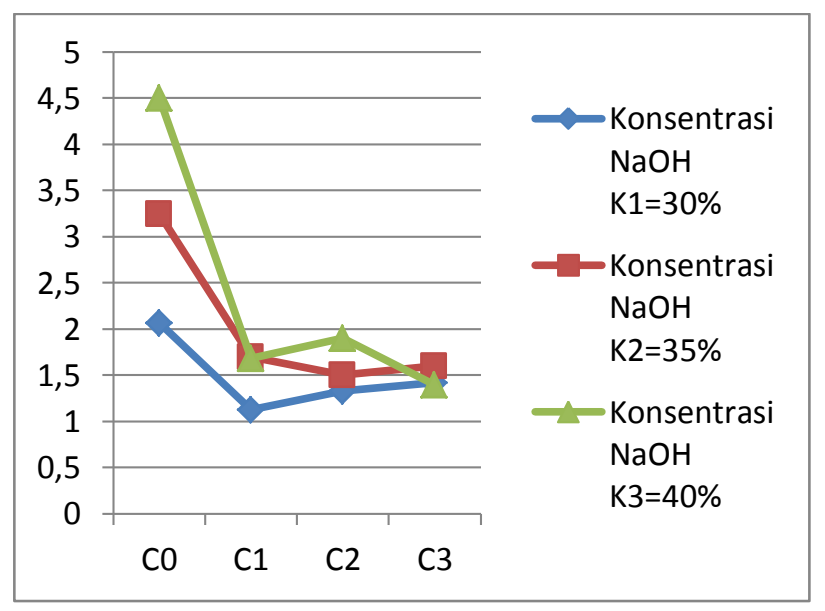

Gambar 7. Grafik hasil pengukuran kekerasan sabun karika menggunakan penetrometer

Hasil pengukuran kekerasan sabun berkisar antara 1,13 sampai dengan 4,5. Dari grafik di atas diketahui bahwa konsentrasi sari buah karika berbanding terbalik dengan konsentrasi $\mathrm{NaOH}$, di mana semakin tinggi konsentrasi sari buah karika maka kekerasan sabun semakin rendah, sedangkan semakin tinggi konsentrasi $\mathrm{NaOH}$ maka kekerasan sabun semakin tinggi. Sabun paling keras adalah sabun tanpa penambahan sari buah karika (CO). Hal ini selaras dengan hasil pengujian kadar air sabun, di mana semakin rendah kadar air sabun maka kekerasan sabun juga semakin tinggi.

\section{Organoleptik sabun}

Uji organoleptik dilakukan untuk mengetahui tingkat kesukaan panelis terhadap produk sabun karika. Uji organoleptik sabun karika menggunakan metode uji hedonik. Data hasil uji organoleptik disajikan pada Gambar 8. 


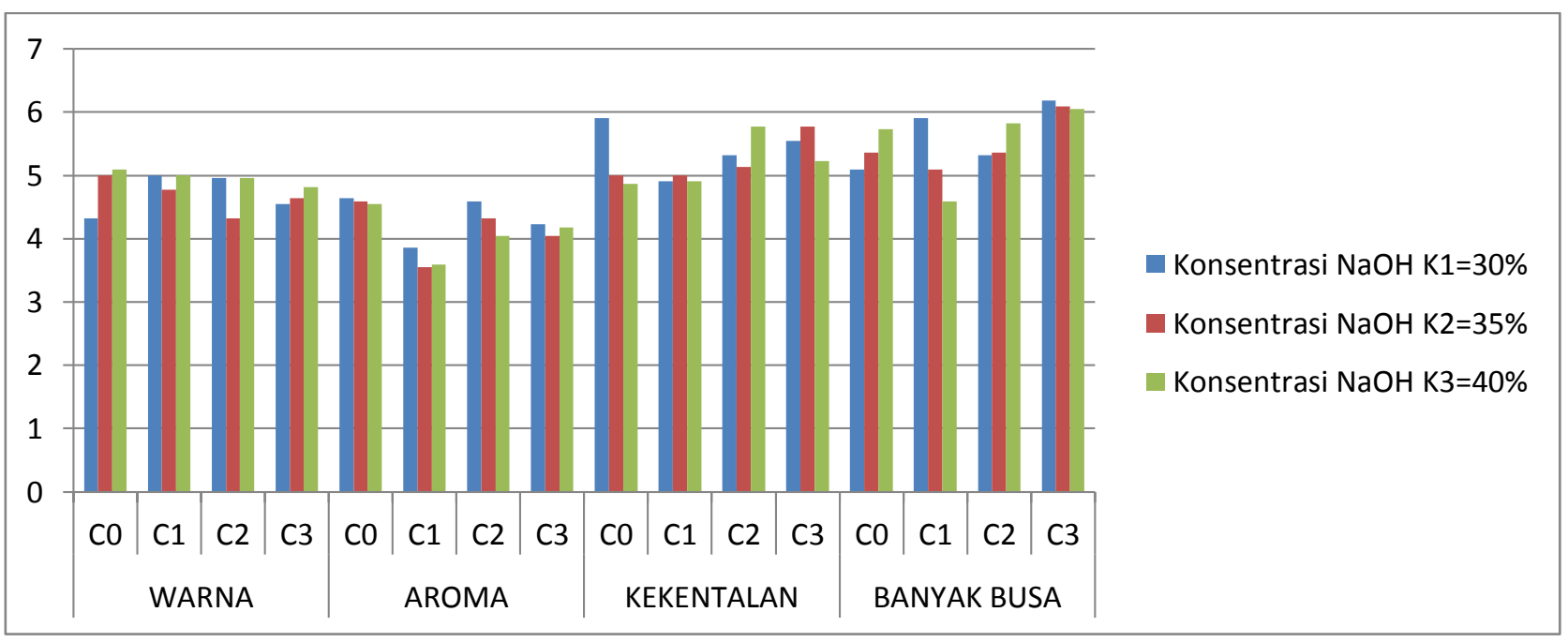

Gambar 8. Diagram hasil uji organoleptik sabun karika

Dari data di atas diketahui bahwa tingkat kesukaan panelis berkisar antara 3,5 (perlakukan C1K2) sampai dengan 6,1 (perlakukan C3K1) yang berarti bahwa rata-rata panelis tidak suka atau netral terhadap produk sabun karika. Sehingga dapat dikatakan tingkat kesukaan panelis terhadap produk sabun karika rendah. Maka, formulasi ulang sabun karika ini perlu dilakukan.

Secara alami buah karika yang telah masak memiliki aroma yang harum, seperti perpaduan aroma buah mangga dan buah nangka, hal ini menjadi pertimbangan peneliti untuk tidak menambahkan parfum pada proses pembuatan sabun mandi. Tetapi setelah ditambahkan ke bahan sabun, aroma buah karika menghilang. Menurut Minarno (2015) dalam hasil penelitiannya menyatakan bahwa pada buah $C$. pubescens dimungkinkan tidak mengandung minyak atsiri karena tidak diperoleh residu dengan bau yang khas setelah larutan uji diuapkan pada cawan porselen, sehingga perlu dilakukan pengujian terkait keberadaan minyak atsiri pada buah karika.

\section{KESIMPULAN}

Formulasi sabun karika hasil penelitian terdiri dari bahan utama sari buah karika, minyak kelapa sawit, $\mathrm{NaOH}$, Cocamide-DEA, dan aquades yang dilakukan dengan metode hot process. Hasil uji kimia sabun karika meliputi kadar air, jumlah asam lemak, asam lemak bebas/alkali bebas, lemak tak tersabunkan, $\mathrm{pH}$ menunjukkan hasil yang belum sesuai dengan SNI sabun mandi padat (BSNI, 1994), sedangkan untuk minyak mineral secara keseluruhan hasilnya negatif telah sesuai dengan SNI. Ada perbedaan signifikan antar perlakuan terhadap kadar air, semakin tinggi proporsi volume air pada bahan dasar sabun maka semakin tinggi kadar air sabun. Hasil uji fisika sabun menunjukkan busa yang dihasilkan banyak dan stabil, sedangkan untuk kekerasan sabun menunjukkan bahwa konsentrasi sari buah karika berbanding terbalik dengan 
kekerasan sabun, di mana semakin tinggi konsentrasi sari buah karika maka kekerasan sabun semakin rendah dan sebaliknya.

Hasil uji organoleptik menunjukkan bahwa tingkat kesukaan panelis berkisar antara 3,5 sampai dengan 6,1 yang berarti bahwa rata-rata panelis tidak suka atau netral terhadap produk sabun karika, dengan kata lain tingkat kesukaan panelis terhadap produk sabun karika rendah. Saran dari kegiatan penelitian ini adalah sari buah karika dapat dicoba untuk diaplikasikan pada pembuatan sabun mandi cair.

\section{DAFTAR PUSTAKA}

Abdullah, B. J., Nasreen, R., \& Ravichandran, N. (2012). A comprehensive review of consumption pattern and strategies in cosmeceutical market with a focus on dermaceuticals in Indian market. International Journal of Scientific and Research Publications, 2(2), 176-179.

Amin, H. (2006). Kajian penggunaan kitosan sebagai pengisi dalam pembuatan sabun transparan. Prosiding Neminar Nasional.

Arlianti, D. (2018). Penggunaan kitosan silver sebagai pengisi dalam pembuatan sabun transparan antibakteri [Skripsi, Universitas Sumatera Utara]. http://repositori.usu.ac.id/handle/1234 56789/8420

Ashfaq, M., \& Ali, M. (2017). Impact of Celebrity Endorsement on Consumer Buying Behavior in FMCG Sector of Pakistan. Oman Chapter of Arabian Journal of Business and Management Review, 34(5627), 1-12.

Betsy, K. J., Jilu, M., Fathima, R., \& Varkey, J. T. (2013). Determination of alkali content $\&$ total fatty matter in cleansing agents.
Asian Journal of Science and Applied Technology, 2(1), 8-12.

BSNI. (1994). SNI Nomor 06-3532-1994 tentang sabun mandi padat. Badan Standarisasi Nasional Indonesia.

BSNI. (2006). Petunjuk Pengujian Organoleptik dan atau Sensori (SNI-01-2346-2006). Badan Standarisasi Nasional Indonesia.

Choir, I. (2015). Formulasi sabun padat dengan menggunakan minyak kelapa dan minyak kakao [PhD Thesis]. Politeknik Pertanian Negeri Samarinda.

Doni, S. (2018). Formulation of kaolin solid soap with varying coconut oil and stearic acid concentration for cleansing severe najis. [Tugas Akhir, UIN Syarif Hidayatullah]. http://repository.uinjkt.ac.id/dspace/ha ndle/123456789/42325

Dunn, K. M. (2009). Time and temperature in soap making. http://cavemanchemistry.com/HsmgTe mperature2009.pdf

Dunn, K. M. (2010). Scientific soapmaking: The chemistry of the cold process. Clavicula press.

Hassali, M. A., Al-Tamimi, S. K., Dawood, O. T., Verma, A. K., \& Saleem, F. (2015). Malaysian cosmetic market: Current and future prospects. Pharmaceut Reg Affairs, 4(4), 155-157.

Hidayat, S. (2001). Potensi dan prospek pepaya gunung (Carica pubescens Lanne \& K. Koch) dari Sikunang, pegunungan Dieng, Wonosobo. Prosiding seminar sehari, 89-95.

http://www.dbriptek.lipi.go.id/cgi/penja ga.cgi?tampildetil\&publikasi\&99752356 7\&1177\&\&997523567\&

Kenna. (2016). How to better understanding water discounts when you make soap. Modern

Soapmaking. https://www.modernsoapmaking.com/l ye-solution-in-soapmaking/

Kusnadi, K., Tivani, I., \& Amananti, W. (2016). Analisa kadar vitamin dan mineral buah karika dieng (Carica pubescens lenne) dengan menggunakan spektrofotometri UV-VIS dan AAS. Parapemikir: Jurnal Ilmiah Farmasi, 5(2), 81-87. 
http://dx.doi.org/10.30591/pjif.v5i2.384 .g362

Laily, A. N., Suranto, S., \& Sugiyarto, S. (2012). Karakterisasi Carica pubescens di Dataran Tinggi Dieng, Jawa Tengah berdasarkan sifat morfologi, kapasitas antioksidan, dan pola pita protein. Bioteknologi Biotechnological Studies, 9(1), 16-21.

Minarno, E. B. (2015). Skrining fitokimia dan kandungan total flavanoid pada buah Carica pubescens lenne \& k. Koch di kawasan Bromo, Cangar, dan dataran tinggi Dieng. el-Hayah, 5(2), 73-82.

Nadarajan, R., \& Ismail, R. (2011). Performance and microstructural study on soap using different fatty acids and cations. Journal of Surfactants and Detergents, 14(4), 463-471.

Ogunsuyi, H. O., \& Akinnawo, C. A. (2012). Quality assessment of soaps produced from palm bunch ash-derived alkali and coconut oil. Journal of Applied Sciences and Environmental Management, 16(4), 363-366.

Oluwatoyin, S. M. (2011). Quality soaps using different oil blends. Journal of Miicrobiology and Biotechnology Research, 1(1), 29-34.

Putri, W. E. S. (2017, September). The quality of transparent soap with addition of moringa leaf extract. 1st International Conference on Social, Applied Science and Technology in Home Economics (ICONHOMECS 2017). https://doi.org/10.2991/iconhomecs17.2018.22

Sameng, M. W. (2013). Formulasi sediaan sabun padat sari beras (Oryza sativa) sebagai antibakteri terhadap Staphylococcus epidermidis [Thesis, Universitas Muhammadiyah Surakarta]. http://eprints.ums.ac.id/27308/

Sari, T. I., Kasih, J. P., \& Sari, T. J. N. (2010). Pembuatan sabun padat dan sabun cair dari minyak jarak. Jurnal Teknik Kimia, 17(1), 28-33.
Whitlock, R. (2010). Hot soap making the complete guide. http://www.sudsandwax.com/

Widyasanti, A., Farddani, C. L., \& Rohdiana, D. (2017). Pembuatan sabun padat transparan menggunakan minyak kelapa sawit (Palm oil) dengan penambahan bahan aktif ekstrak teh putih (Camellia sinensis). Jurnal Teknik Pertanian Lampung (Journal of Agricultural Engineering), 5(3), 125-136.

Wijesundera, G., \& Abeysekera, R. (2010). Factors influencing the demand of beauty soap among female consumers in the greater Colombo region [Thesis, Universit of Kelaniya Sri Lanka]. http://repository.kln.ac.lk/handle/1234 $56789 / 4569$ 